\title{
Retrobulbar haemorrhage associated with chronic Gingko biloba ingestion
}

\author{
K C S Fong, P E Kinnear
}

Postgrad Med J 2003;79:531-532

Retrobulbar haemorrhage is a rare and potentially sight threatening complication after peribulbar local anaesthetic injection for cataract surgery. A case is reported of a woman who developed this complication and was subsequently found to have been taking Gingko biloba extract tablets which may have predisposed her to developing the haemorrhage.

A 65 year old woman was admitted for routine phacoemulsification and intraocular lens implantation to her left eye. She had no past medical history and denied taking any medications. Her preoperative blood pressure was 135/70 $\mathrm{mm} \mathrm{Hg}$ and preoperative visual acuity in her left eye was 6/18 unaided. For local anaesthesia, a 25 gauge needle of $25 \mathrm{~mm}$ length containing $5 \mathrm{ml}$ \% lignocaine and $5 \mathrm{ml} 0.75 \%$ bupivicaine was inserted in the inferotemporal region of her left orbit. Immediately after injection of $5 \mathrm{ml}$ of the local anaesthetic mixture, there was sudden proptosis and bruising of her lower lid which extended medially and superiorly. The patient complained of pain in her left eye and reduction of vision. Her eyelids were tense and her ocular movements restricted. A diagnosis of acute retrobulbar haemorrhage was made and urgent lateral canthotomy and inferior cantholysis was performed to decompress the orbit.

She was re-examined two hours later and no longer had any proptosis or restriction of ocular movement. The visual acuity in her left eye was unchanged at 6/18 unaided, the intraocular pressure in the left eye was $16 \mathrm{~mm} \mathrm{Hg}$, and her left optic disc and fundus appeared healthy with no evidence of any vascular occlusion. Further detailed questioning revealed that she had been taking Gingko biloba extract tablets $40 \mathrm{mg}$ three times a day for the past two years. Haematological investigations showed a normal blood count, prothrombin and partial thromboplastin times. Serum urea, creatinine, and liver function tests were normal.

\section{DISCUSSION}

Gingko biloba extract is a standardised extract of the leaves of Gingko biloba trees. It is widely advertised as a panacea for a wide range of conditions including dementia, peripheral vascular disease, memory impairment, erectile dysfunction, and age related macular degeneration. Gingko biloba extract exerts its effect through its influence on prostaglandin metabolism, antagonism of platelet aggregating factor, and free radical scavenging. ${ }^{1}$ The inhibition of platelet activating factor raises the greatest concern for the perioperative period because platelet function may be altered especially when combined with other anticoagulants like warfarin. ${ }^{2}$ There have been cases of spontaneous intracranial bleeding, ${ }^{3-5}$ spontaneous hyphaema, ${ }^{6}$ and postoperative bleeding ${ }^{78}$ being attributed to use of Gingko biloba extract (table 1). The bleeding time was found to be increased in two of those cases. ${ }^{3}{ }^{4}$ However, bleeding time is considered to be a very crude measure of platelet function with limited clinical utility ${ }^{9}$ and this was not performed in our patient.

It is estimated that up to $12 \%$ of the population in the United States uses herbal medications, ${ }^{10}$ but more than $70 \%$ of patients in another study failed to disclose their herbal medicine use during routine preoperative assessment. ${ }^{11}$ Reasons for this include patient-held beliefs that doctors are not knowledgeable about herbal medications, fear of admitting their use of unconventional therapies, and the fact that they do not consider these substances to be medications. Apart from Gingko biloba extract, other commonly used herbal medicines that are thought to affect blood clotting include garlic, ginger, and ginseng extracts.

Table 1 Previous reports of haemorrhage associated with Gingko biloba ingestion

\begin{tabular}{|c|c|c|c|}
\hline Reports & Type of haemorrhage & $\begin{array}{l}\text { Dose of Gingko biloba ingestion } \\
\text { and duration of ingestion }\end{array}$ & Remarks \\
\hline Vale $(1997)^{3}$ & Spontaneous subarachnoid haemorrhage & $\begin{array}{l}40 \mathrm{mg} \text { four times a day for } \\
6 \text { months }\end{array}$ & $\begin{array}{l}\text { Increased bleeding time was found. This } \\
\text { improved after stopping the Gingko biloba } \\
\text { extract }\end{array}$ \\
\hline $\begin{array}{l}\text { Rowin et al } \\
(1996)^{4}\end{array}$ & Spontaneous bilateral subdural haematoma & $\begin{array}{l}40 \mathrm{mg} \text { three times a day. } \\
\text { Duration of use not stated }\end{array}$ & Increased bleeding time was found \\
\hline $\begin{array}{l}\text { Benjamin et al } \\
(2001)^{5}\end{array}$ & Spontaneous intracerebral haematoma & $\begin{array}{l}40 \mathrm{mg} \text { three times a day for } \\
18 \text { months }\end{array}$ & Normal cerebral angiography \\
\hline $\begin{array}{l}\text { Rosenblatt et al } \\
(1997)^{6}\end{array}$ & Multiple spontaneous episodes of hyphaema & $40 \mathrm{mg}$ twice a day for 1 week & $\begin{array}{l}\text { Episodes of hyphaema stopped after Gingko } \\
\text { biloba extract was discontinued }\end{array}$ \\
\hline $\begin{array}{l}\text { Fessenden et al } \\
(2001)^{7}\end{array}$ & $\begin{array}{l}\text { Postoperative bleeding after laparoscopic } \\
\text { cholecystectomy }\end{array}$ & $\begin{array}{l}40 \mathrm{mg} \text { twice a day. Duration not } \\
\text { stated }\end{array}$ & $\begin{array}{l}100 \mathrm{~g} / \mathrm{l} \text { of haemoglobin was lost in the } 1 \text { st } 48 \\
\text { hours after uncomplicated surgery }\end{array}$ \\
\hline \multirow[t]{2}{*}{$\begin{array}{l}\text { Haveser et al } \\
(2002)^{8}\end{array}$} & $\begin{array}{l}\text { 1. Large subphrenic haematoma after liver } \\
\text { transplantation }\end{array}$ & Dose and duration of ingestion & Gingko biloba extract was being ingested \\
\hline & $\begin{array}{l}\text { 2. Spontaneous unilateral vitreous haemorrhage } \\
3 \text { weeks after liver transplant }\end{array}$ & & $\begin{array}{l}\text { bleeding occurred after the extract was } \\
\text { discontinued }\end{array}$ \\
\hline
\end{tabular}


The risk of developing an acute retrobulbar haemorrhage after peribulbar injection in the absence of anticoagulation medication ingestion is estimated to be only $0.074 \% .{ }^{12}$ We feel that this is an extremely low risk and that in the case of our patient, her chronic ingestion of Gingko biloba extract predisposed her to developing the haemorrhage. However, this is only an association and we cannot conclusively prove that the extract caused the haemorrhage.

While we are aware that the connection of Gingko biloba extract use with haemorrhage is anecdotal, we feel that it is important that patients should be specifically asked about herbal medication use in any preoperative assessment to highlight any possibility of a bleeding tendency. In the case of our patient, we could have then avoided the use of local anaesthetic injection and performed the operation under topical or general anaesthetic.

\section{Authors' affiliations}

K C S Fong, P E Kinnear, Department of Ophthalmology, Charing Cross Hospital, London

Correspondence to: Mr Kenneth Fong, Department of Ophthalmology, Hillingdon Hospital, Uxbridge UB8 3NN, UK; fongcsk@yahoo.co.uk

Submitted 7 January 2003

Accepted 9 March 2003

\section{REFERENCES}

1 Ang-Lee MK, Moss J, Yuan C-S. Herbal medicines and perioperative care. JAMA 2001;286:208-16.

2 Gianni LM, Dreitlein WB. Some popular OTC herbals can interact with anticoagulant therapy. US Pharmacist 1998;23:83-4.

3 Vale S. Subarachnoid haemorrhage associated with Gingko biloba. Lancet 1998:352:36.

4 Rowin J, Lewis SL. Spontaneous bilateral subdural haematomas associated with chronic Gingko biloba ingestion. Neurology 1996;46:1775-6

5 Benjamin J, Muir T, Briggs K, et al. A case of cerebral haemorrhage-can Gingko biloba be implicated? Postgrad Med J 2001;77:112-3.

6 Rosenblatt M, Mindell J. Spontaneous hyphema associated with ingestion of Gingko biloba extract. N Engl J Med 1997;336:1 108.

7 Fessenden JM, Wittenborn W, Clarke L. Gingko biloba: a case report of herbal medicine and bleeding postoperatively from a laparoscopic cholecystectomy. Am Surg 2001;67:33-5.

8 Hauser D, Gayowski T, Singh N. Bleeding complications precipitated by unrecognised Gingko biloba use after liver transplantation. Transpl Int 2002:15:377-9.

9 Thompson CM, Steinhubl SR. Monitoring of platelet function in the setting of glycoprotein Ilb/llla inhibitor therapy. Journal of Interventional Cardiology 2002;15:61-70

10 Eisenberg DM, Davis RB, Ettner SL, et al. Trends in alternative medicine use in the United States, 1990-1997: results of a follow-up study. JAMA 1998:280:1569-75.

11 Kaye AD, Clarke RC, Sabar R, et al. Herbal medications: current trends in anestheiology practice-a hospital survey. J Clin Anesth 2000; 12:468-71

12 Davis II DB, Mandel MR. Efficacy and complication rate of 16224 consecutive peribulbar blocks. J Cataract Refract Surg 1994;20:327-37.

\section{IMAGES IN MEDICINE.}

\section{Three channelled aortic dissection}

A 37 year old man with Marfan's syndrome complained of a second episode of sudden chest pain. He had undergone Bentall's operation at another hospital because of a diagnosis of Stanford type A aortic dissection. Enhanced computed tomography showed a three channelled aortic dissection in the thoracic descending aorta, having one occluded lumen and two patent lumens (fig 1A). The former was a thrombosed false lumen deriving from the previous dissection, and the latter was a new dissection from the previous true lumen (fig 1B). This case indicates that thrombus of the false lumen in a patient with chronic aortic dissection does not always mean a stable condition. Two years later he died suddenly of an unknown cause.

S Yoshida, M Shidoh

Department of Radiology, Muroran City General Hospital, Yamate-chou 381, Muroran 051-8512, Japan; satyoshi@chive.ocn.ne.jp
A
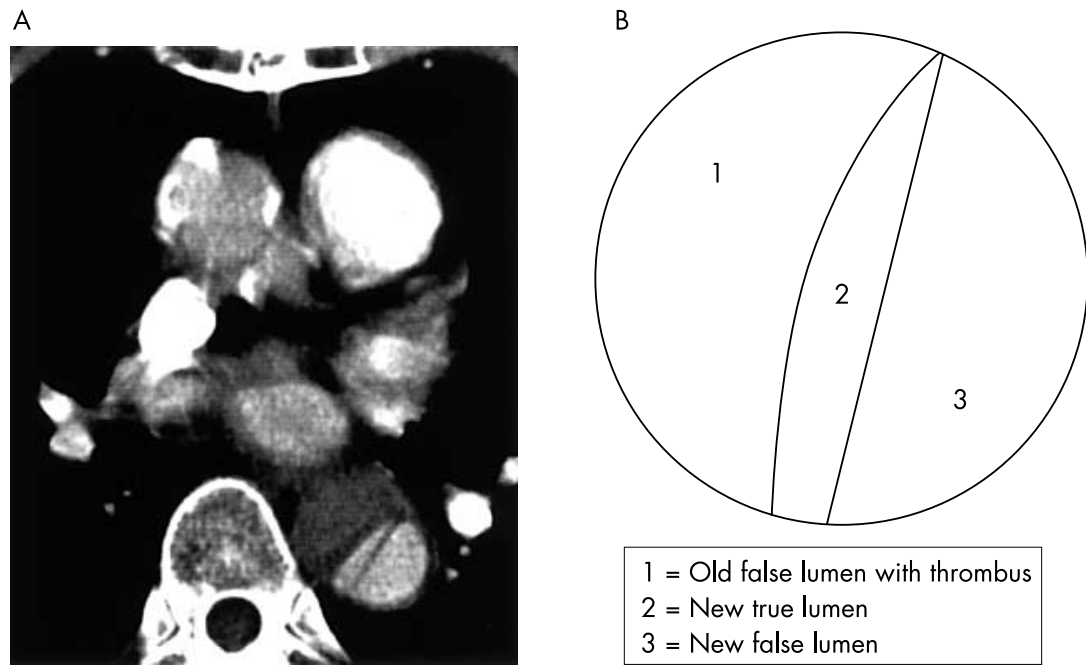

$1=$ Old false lumen with thrombus

2 = New true lumen

$3=$ New false lumen

Figure 1 (A) Enhanced computed tomography showing a three channelled aortic dissection in the thoracic descending aorta and (B) schematic diagram showing old false, new true, and new false lumens. 